\title{
APPLYING THE RESEARCH SKILLS FOR DEVELOPMENT OF BACHELOR'S THESIS
}

\author{
Mirdza Paipare \\ Liepajas University, Latvia \\ Līga Engele \\ Liepajas University, Latvia \\ Olga Blauzde \\ Liepajas University, Latvia
}

\begin{abstract}
We live in the age when research skills are required regardless of person's field of activity and experience, therefore it is important to acquire the research skills as key competences already in the school years. Also it is possible to purposefully develop the research skills working on the course papers, bachelor's thesis, master's thesis and doctoral dissertation. In Liepaja University, the Bachelor's study program Teacher/ Music teacher gives the students the opportunity to participate in the development of science, ensuring the academic research principles in the science of pedagogy.

The authors of this article analyse the choice of research topics selected by the students of Liepaja University, study program Teacher/ Music teacher, as well as the content of the Bachelor's papers, evaluating the applied research skills. The aim of this research: to explore the students' ability to apply the research skills in the process of Bachelor's thesis development. The research method: This study is designed as analysis and review of the defended Bachelor's thesis. As the result, the topicality and specifics of the Bachelor's papers is evaluated, keeping in mind the selected qualifications in the context of lifelong education, also analysing the students' ability to apply the research skills while working on Bachelor's thesis.
\end{abstract}

Keywords: Bachelor's thesis, life-long education, music teacher, research skills.

\section{Introduction}

In nowadays' pedagogy, independent learning skills and judgement building skills are the primary means of personal self-realization. Working on bachelor's thesis students use knowledge and skills gained in professional and general education and practical life experience and activity goals (Vygotsky, 1986; Čehlova, 2002; Rudzītis, 1997; Žogla, 2001; Maslo, 2006).

Paying attention to research field in educational institutions, integrating scientific researches and technology development in study process improves the quality of higher education and strengthens the collaboration between higher education institutions and employers (Bundule \& Jansons). The process of writing bachelor's thesis reveals students' diverse experiences of individual professional 
development that are based on individual personal traits, motive for choosing themes for the bachelor's thesis that are personally significant.

Teacher training programmes in Liepajas University have quite a long history. Liepajas University (LiepU) as Liepajas Pedagogical Institute was founded in 1954 on the basis of Teaching Institute. Till the beginning of nineties university trained mostly primary school and nursery school pedagogues, math teachers, Latvian and literature teachers for entire country. If official statistics were completed, we could find a teacher who has graduated from Liepajas University in every region of Latvia. Liepajas University in its development has gone through many changes in its title: Liepajas Pedagogical Institute, Liepajas State Pedagogical Institute, Vilis Lācis Liepaja State Pedagogical Institute, again Liepajas Pedagogical institute, Liepajas Pedagogical Higher School, Liepajas Pedagogical Academy and Liepajas University (since 16th july 2008).

During the time from 1997 to 2010 more than 60 music teachers have been trained in Liepajas University. Since 2011, study programme has been transformed and exists with title Teacher/Music teacher. In its obligatory courses (A area) students in various modules learn knowledge, skills and acquirements necesary for all subject teachers. During the time period from 2010 to 2018, in study programme Teacher/Music teacher 43 bachelor's theses have been elaborated and defended.

Lifelong learning is known for a long time. In the context of European education, it has come forward in 20th century during sixties and seventies, but in Latvian it has become current only in the last decade.

Cross (1981) defines lifelong learning as self-motivated growth, which means - to understand oneself and the world, learn skills and improve abilities, that are truly real values which can never be lost. Accenting the necessity of music teacher's profession in the context of latvian cultural identity, it is also important to abide by lifelong learning principle in study programme organization as well. As L. Kriumane (2004) writes: "first aspect of lifelong learning, as study programme development principle, is: traditional and for contemporary educational system too superficial and simplified understanding of the term lifelong learning, as education that has been started in childhood, continued in higher education establishments after high school, but after higher education is continued as professional qualification improvement in self-study form or as attendance of some courses in further education (even seminars and conferences)".

In nowadays perspective the term lifelong learning in aspect of study programme development, is explained as a chance to continue learning in master or doctor studies or even return to educational system various times to obtain new, additional qualification. Real-life evidence shows that the change of first qualification or basic profession often happens into a completely different 
direction. In authors' opinion such a student transition to another educational level (to master and even doctor studies) confirms the latest explanation of lifelong learning. To achieve transition to the next level in education, students need to develop research skills during the studies.

While doing research activities, students' level of these skills can differ. At the beginning students work on course paper's goals, analysing those together with consultant of the paper. The role of university lecturer is to point out the problem, help students to uncover most efficient ways in organizing independent work, and to share their knowledge and experience. The more sustainable research skills become, the bigger the student's level of independence will become. Development of research skills is considered both - cognitive process (because it demands from students active awareness about their research process and its results) and studentlecturer interaction process, because it is based on development of motivation and attitude in the student-lecturer collaboration (Odina, Linde, \& Gerke, 2016).

Mastering research skills contributes to students' confidence in their own powers, to the trust in their research activity in general, which makes a positive experience in research consistent and allows students to judge external research factors in the context of their own experience. While using the research approach in the pedagogical practice process, students acquire the ability to obtain data for the experimental part, the ability to observe pedagogical situations, interpret data, skills to offer answers, explanations and predictions (Kalnina, 2004).

\section{Research organization and results}

Research is designed as a review of all presented bachelor's theses. As the result, the topicality and specifics of the Bachelor's theses are evaluated, keeping in mind the selected qualifications in the context of lifelong education, also analysing the students' ability to apply the research skills while working on Bachelor's thesis.

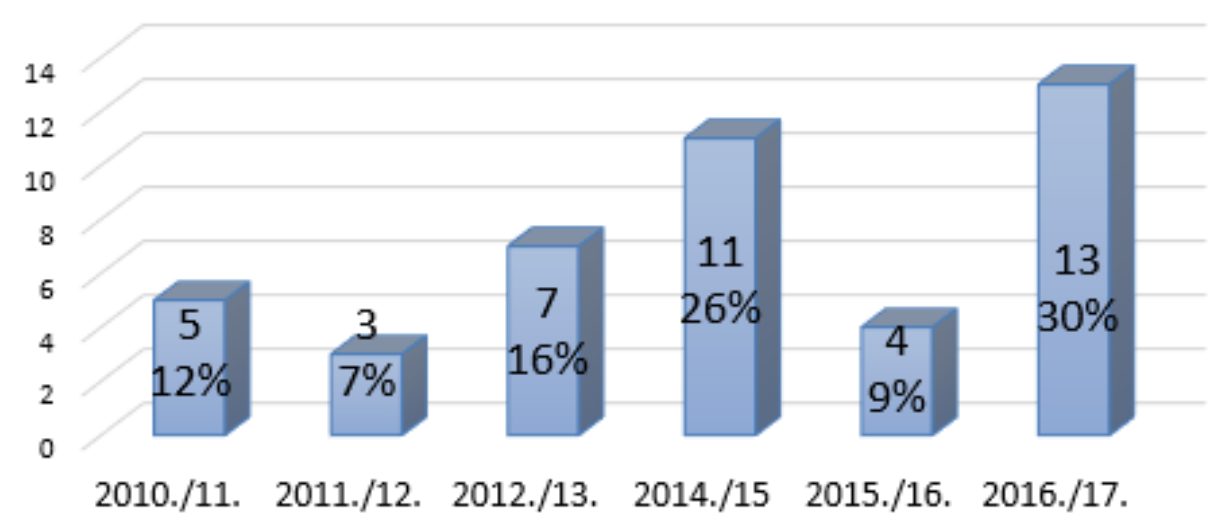

Fig. 1. Number of defended bachelor theses in each study year (2010-2018) 
During the time period from 2010 to 2018, there were 43 bachelor's theses elaborated and defended (see Fig. 1). Most of bachelor's theses were defended in $2014 / 2015$ study year (26 \% of researches or 11 papers) and in 2016/2017 study year (30\% of researches or 13 papers).

\section{Research topics and explorable features}

Summarizing and analysing topics of bachelor's theses, authors concluded that (see Fig. 2):

1) most of researches (20 bachelor's theses) are done on gradeschoolers, emphasizing:

a) importance of musical skill development;

b) possibilities to develop musical intonation skills for off-tune singers;

c) necessity to use vocal exercises;

d) application of jazz music making to music lessons;

e) comparison of music listening approaches in Latvia and Belgium.

2) raising the question of improving the quality of music making and artistic performance, as well as reducing performance anxiety for adolescents and youth, 17 bachelor's theses were defended;

3) 9 bachelor's theses were written about use of varied methods in music lessons in preschool age group.

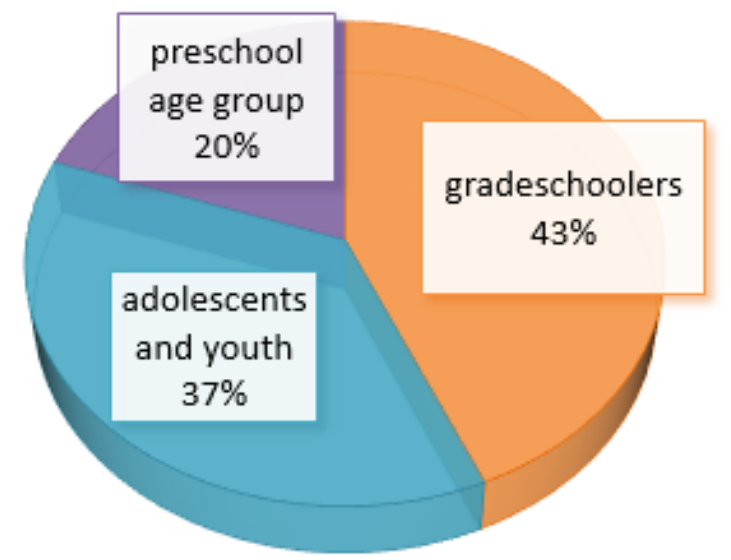

Fig. 2. Researched age groups in bachelor's theses

Some researches by future music pedagogues emphasize also the necessity for modern technology application in music lessons, but most of them reveal the significance of motivation, socialisation, creative activities and use of interactive methods in general education schools and interest-related education. By analysing bachelor's theses in music, authors of this article established that students' 
researches cover most of the learning principles listed as important in learning process in The National Basic Education Standard. The most significant in music are:

1) self-expression and creative aspect (pupils acquire creative experience by participating in the artistic process, developing imagination and fantasy, knowing their abilities and understanding the meaning of creative self-expression in a person's life);

2) analytically critical aspect (the pupil acquires the experience of intellectual activity, learning to think independently and critically, learning about the link between music in different eras);

3) valuing (moral and aesthetic) aspect (getting to know various types of music, pupils get the opportunity to complete their system of values and attitudes, to develop their aesthetic taste, to develop a national identity and self-esteem);

4) social (cooperation) aspect (the pupil develops cooperation skills in collective music making);

5) the aspect of communication (pupils express their feelings and emotions, characterizing the music, express their attitude towards it);

6) the aspect of learning and practical activities (the pupil learns and uses the possibilities offered by the learning environment and modern information technologies).

In The Basic Elementary Education Standard in regards of the subject Music it is stated that the musical training content consists of three structural components:

1) musical language (48\%);

2) musical perception and artistic performance (47 \%);

3) music as an element of culture (5\%).

The bachelor's theses of music teacher's programme pay a lot of attention to enforcing the possibilities and quality of the content and tasks in the subject, provoking the question of the necessity to use more advanced methods for all three structural components in musical training.

Interesting researches and insights are reflected in the bachelor's theses on artistic performance, the importance of increasing the music perception, the reduction of performance anxiety, ability and development at different age groups, and the significance of musical games in the process of personality formation.

Much attention in bachelor's theses is paid to the structural component of musical perception and creative activity and to three types of musical activities (see Fig. 3) - singing, instrument playing/music making and music listening activity, emphasizing the importance of gaining personal experience in the music playing process. 


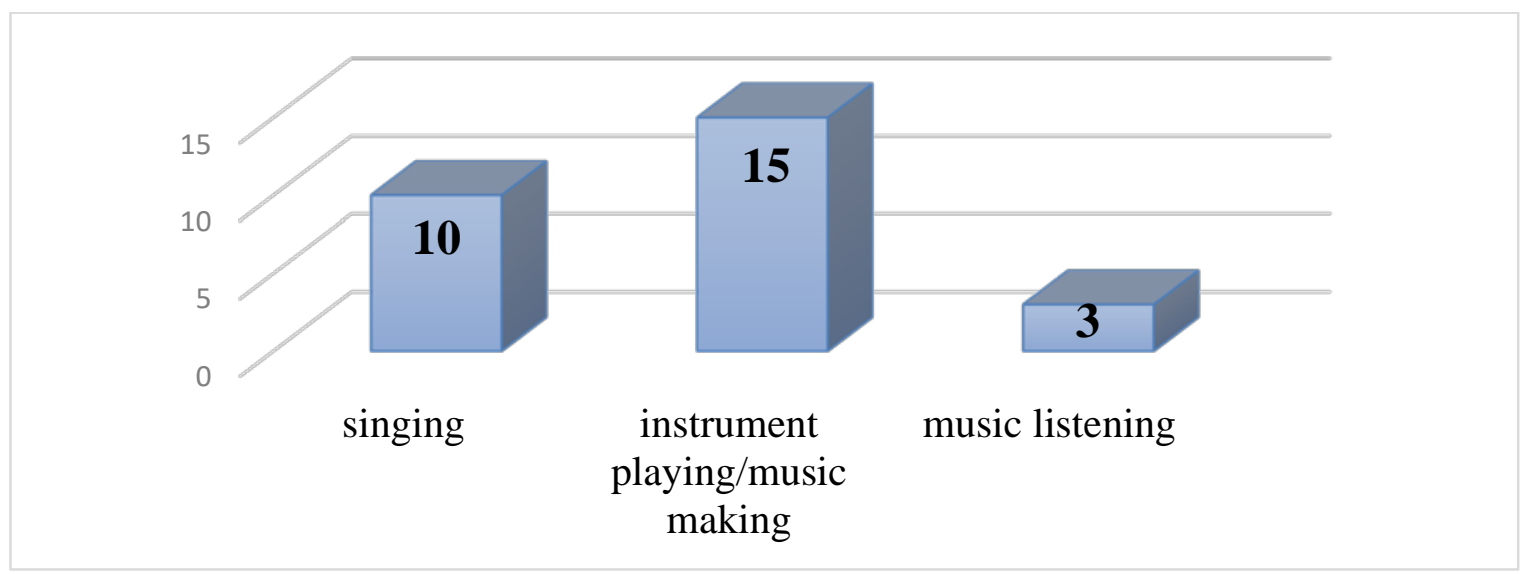

Fig. 3. Reviewed musical activity types in bachelor's theses

\section{Conclusions}

1) In nowadays perspective the term lifelong learning is being explained as a chance to continue learning in master or doctor studies or even study various times to obtain new, additional qualification.

2) To graduate and transition to the next level of education (master, doctor) students need to develop research skills. Mastering them also helps students to gain confidence in their own abilities, trust in their research activity in general, make a positive experience in research and make it possible to build their own experience.

3) This research is designed as a review of all defended bachelor's theses. During the time period from 2010 to 2018, there were 43 bachelor's theses elaborated and defended.

4) Some researches emphasize also the necessity for modern technology application in music lessons, but most of them reveal the significance of motivation, socialisation, creative activities and use of interactive methods.

5) Most of researches (20 bachelor's theses) are done on gradeschoolers, emphasizing the importance of musical skill development, possibilities to develop musical intonation skills for off-tune singers, necessity to use vocal exercises and application of jazz music making to music lessons, comparison of music listening approaches in Latvia and Belgium.

6) By analysing bachelor's theses in music, authors of this article established that students' researches cover most of the learning principles listed as important in learning process in The National Basic Education Standard.

7) The most significant learning principles in music are: self-expression and creative aspect, analytically critical aspect, valuing (moral and aesthetic) aspect, social aspect, the aspect of communication and the aspect of learning and practical activities. 
8) Much attention in bachelor's theses is paid to the structural component of musical perception and to three types of musical activities - singing, instrument playing/music making and music listening activity, emphasizing the importance of gaining personal experience in the music playing process.

\section{References}

Bundule, M., \& Jansons, J. (2005). Starptautiskā zinātniskā sadarbība. Zināšanu sabiedrību veidojot, 70-93.

Cross, K. P. (1981). Adults as Learners. San Francisco: Jossey-Bass.

Čehlova, Z. (2002). Izzinas aktivitāte mācībās. Rīga: RaKa.

Kalniņa, D. (2004). Pētnieciskās mācīšanās prasmes attīstība dabaszinību apguves procesā. Starptautiskā zinātniskā konference: teorija un prakse skolotāju izglìtībā II, 614-615.

Koḳe, T. (1999). Pieaugušo mācī̌sanās sociāli pedagogiskie pamati. Habilitācijas darba kopsavilkums. Rīga: LU.

Kriumane, L. (2004). Mūžizglītība - viens no mūzikas skolotāju studiju programmu veidošanas principiem. Starptautiskā zinātniskā konference: teorija un prakse skolotāju izglìtībā II, 187-191.

Maslo, E. (2006). Skolēnu, skolotāju, studentu un docētāju spēju pilnveide savas mācīšanās izpētes procesā. Zināšanām uz kompetentu darbību: mācĭšanās antropologiskie, ètiskie un sociālkritiskie aspekti, 57-59.

Mācību priekšmeta standarts 1.-9.klasei, 14.pielikums. Retrieved from https://likumi.lv/ doc.php?id=268342\#piel14\&pd=1

Odiṇa, I., Linde, L., \& Gerke, S. (2016). Studentu patstāvīgās mācī̌sanās prasmju attīstība universitātes studiju procesā. Pedagogija: teorija un prakse, VII zinātnisko rakstu krājums, 102-115.

Rudzītis, G. (1997). Gribas un rakstura veidošana mācību darbā un pašizglītībāa. Jelgava: Latvijas Lauksaimniecības universitāte.

Vygotsky, L. (1986). Thought and Language. Cambridge, Mass: MIT Press.

Žogla, I. (2001). Didaktikas teorētiskie pamati. Rīga: RaKa. 